Int. J. Dev. Biol. 53: 323-334 (2009)

doi: $10.1387 / \mathrm{ijdb} .082652 \mathrm{~ns}$

\title{
Many paths to one goal? The proteins that recognize methylated DNA in eukaryotes
}

\author{
NOBUHIRO SASAI and PIERRE-ANTOINE DEFOSSEZ* \\ CNRS UMR 218, Institut Curie, Paris, France
}

\begin{abstract}
DNA methylation is an epigenetically inherited chemical modification that is associated with transcriptional silencing and is essential for mammalian development. The DNA methylation signal is read out by methyl-CpG binding proteins (MBPs) that specifically bind to methylated DNA. Three structurally divergent families of MBPs have been identified so far: the MBD family, the SRA family and a family of proteins with Zinc fingers. In this review, we describe how the distinct families of methyl-CpG binding proteins have evolved, how they each recognize and maintain the DNA methylation mark, and finally how they turn this mark into biological effect.
\end{abstract}

KEY WORDS: DNA methylation, methyl-CpG binding proteins, MBD domain, zinc finger, SRA domain

\section{Introduction}

DNA methylation is an epigenetically inherited chemical modification, which can occur at the adenine or cytosine bases of DNA molecules. Methylated DNA is found in various species from bacteria to humans. In bacteria, the DNA methylation system is used in combination with methylation-sensitive restriction enzymes primarily to protect the host genomes from invasion by foreign DNA. In eukaryotes, the roles of DNA methylation are much more diverse. In mammals, DNA methylation takes place mainly on the cytosine of CpG dinucleotides and plays crucial roles in $\mathrm{X}$ chromosome inactivation, genomic imprinting, genome stability and transcriptional silencing. DNA methylation is essential for early development (Bird, 2002, Li, 2002).

The methylated DNA signal is read out by a set of proteins which specifically recognize methylated DNA and recruit corepressor complexes to form transcriptionally silenced chromatin structures. In mammals, three structurally distinct types of MethylCpG binding proteins have been identified so far: the MBD family, the SRA family, and a group of proteins with Zinc fingers (Fig. 1). Here, we will review the recent data addressing the roles of these proteins in mammalian cells, and underline their similarities and differences. We will also point out interesting aspects of the evolution of methyl-CpG binding proteins in vertebrates and invertebrates. DNA methylation: an epigenetic mark found in diverse
organisms

The abundance and role of DNA methylation varies greatly between species (Colot and Rossignol, 1999). The genomes of vertebrates are consistently heavily methylated, whereas the DNA methylation patterns vary to a great extent between invertebrate species (Table 1) (Suzuki and Bird, 2008). In mammals, approximately $70 \%$ of CpG sequences are methylated (Bird, 2002). However, the CpG-rich stretches of DNA, mostly associated with gene promoters, that are called CpG-islands usually escape methylation. This rule has exceptions, and some CpG islands are known to undergo methylation during development or in somatic cells (Shen et al., 2007, Weber et al., 2007).

DNA methylation is generated by dedicated enzymes; their signature is a catalytic domain that is found conserved in prokaryotic and eukaryotic organisms (Goll and Bestor, 2005). Mammals have three types of DNA methyltransferases: DNMT1, DNMT2, and the closely related DNMT3a and DNMT3b. DNMT1 acts preferentially on hemi-methylated DNA and contributes to main-

Abbreviations used in this paper: BTB, broad complex, tramtrack and bric à brac; CtBP, C-terminal binding protein; DNMT, DNA methyltransferase; KBS, kaiso binding sequence; MBD, methyl-CpG-binding domain; MBP, methyl-CpG binding protein; SRA, SET and ring finger-associated.

\footnotetext{
*Address correspondence to: Dr. Pierre-Antoine Defossez. CNRS UMR218, Institut Curie, 26 rue d'UIm, 75248 Paris Cedex05, France. Fax +33-1-4633-3016. e-mail: Defossez@Curie.fr - web: http://www.curie.fr/recherche/themes/detail_equipe.cfm/lang/_gb/id_equipe/297.htm
} 
tain the DNA methylation patterns during cell division (Bestor, 1992, Leonhardt et al., 1992). In contrast, DNMT3a and DNMT3b are de novo methyltransferases that act on non-methylated DNA (Okano et al., 1998a, Okano et al., 1999). DNMT2 has comparatively weak DNA methyltransferase activity (Okano et al., 1998b), but instead methylates tRNA (Goll et al., 2006). An important unresolved question is how these proteins are targeted to specific regions to generate the required patterns of DNA methylation.

\section{Essential roles of DNA methylation in embryonic devel- opment}

The levels of DNA methylation in mammals are regulated very dynamically during early development. After fertilization, both maternal and paternal genomes undergo demethylation through mechanisms that are currently unknown. Both genomes become methylated again after implantation ( $\mathrm{Li}, 2002)$. Knockout of the Dnmt1 gene causes a decrease of DNA methylation and results in early embryonic lethality (Li et al., 1992). But is the essential function of DNMT1 to methylate DNA? This important question has been answered very recently: mice expressing a catalytically inactive mutant of DNMT1 show phenotypes identical to those of Dnmt1-null mice, proving that DNA methylation is indeed the essential role of DNMT1 in development (Damelin and Bestor, 2007, Takebayashi et al., 2007). Combined inactivation of Dnmt3a and Dnmt3b genes blocks de novo methylation and also results in embryonic lethality (Okano et al., 1999). In addition to its importance during development, DNA methylation is associated

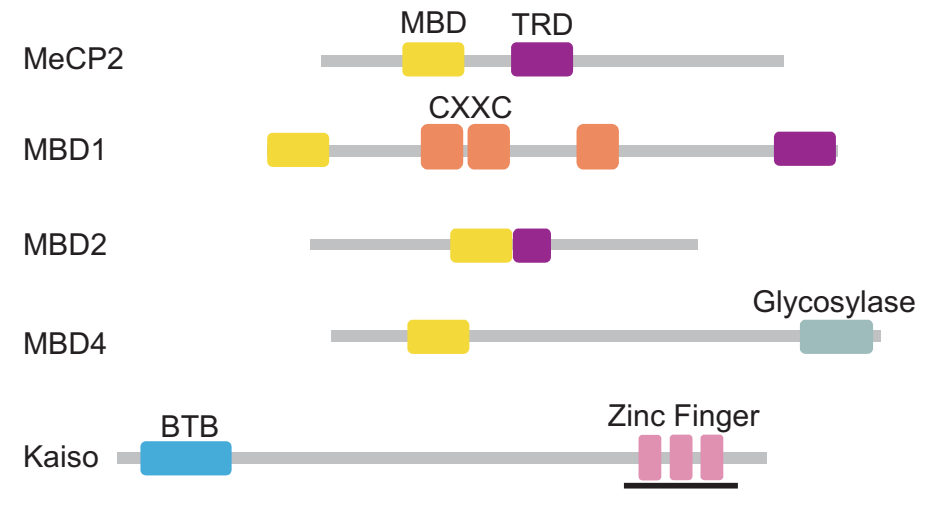

\section{MBD-containing proteins: the original MBPs}

The first proteins shown to specifically bind methylated DNA belong to the MBD family (Fig. 1). Over 15 years ago, the protein MeCP2 was identified and cloned as a component of a methylCpG binding activity (Meehan et al., 1989, Lewis et al., 1992, Meehan et al., 1992). The domain responsible for binding methylated DNA was mapped, and named Methyl-CpG-binding domain (MBD) (Nan et al., 1993). Other proteins containing this motif were then isolated and named MBD1, MBD2, MBD3 and MBD4 (Cross et al., 1997, Hendrich and Bird, 1998). All the MBD proteins bind to DNA in a methylation-dependent manner via the MBD. The only exception is MBD3, which lacks methyl-CpG-binding activity because of amino acid changes at critical positions (Saito and Ishikawa, 2002). MBD4, which contains a thymine glycosylase domain, behaves as a DNA repair enzyme. In mammalian genomes, methylated cytosine is unstable and frequently mutated to thymine by deamination, generating T:G mismatches (Walsh and Xu, 2006). MBD4 preferentially binds to these $\mathrm{T}$ : G mismatches and repairs them, and its deficiency results in the enhancement of CpG mutability and tumorigenesis (Hendrich et al., 1999, Millar et al., 2002).

The solution structure of the MBD
Fig. 1. The human proteins that bind methylated DNA. Three types of domains endow proteins with the ability to recognize methylated DNA: the MBD domain, certain zinc fingers, and the SRA domain. We have represented all the human proteins known to bind methylated DNA at this time. The MBD proteins contain the MBD as well as a trans-repression domain (TRD), CXXC zinc fingers or glycosylase domain. The zinc fingers are depicted by pink rectangles, and those that confer methyl-DNA binding are underlined. The zinc finger family proteins also contain a BTB domain and up to 7 additional zinc fingers. The BTB domain of ZBTB4 is disrupted by an insertion of serine rich sequences. UHRF1 and UHRF2 contain the SRA domain, a Ubiquitin-like domain, a PHD finger and a Ring finger. with various human diseases. Mutations in Dnmt3b cause ICF immunodeficiency, centromeric heterochromatin instability, and facial abnormalities (Hansen et al., 1999, Xu et al., 1999). Defects in genomic imprinting can also cause several human diseases
including Beckwith-Wiedemann syndrome, Prader-Willi syndrome and Angelman syndrome, and are associated with some cancers

\section{ing}

Many studies have established that DNA methylation is associated with transcriptional silencing in mammalian cells. Two of DNA can prevent some transcription factors from binding their target. For instance the binding of CTCF, a chromatin insulator protein, to its target sites is blocked by DNA methylation (Bell and creates binding sites for proteins that specifically recognize methylated DNA. These proteins, called methylated DNA binding proteins (MBPs) (Fig. 1), recruit enzymatic cofactors that modify molecular environment that inhibits gene expression. DNA methylation and histone modifications are tightly connected to establish and maintain a transcriptionally silenced chromatin environment (Fig. 2) (Fuks, 2005). 
A

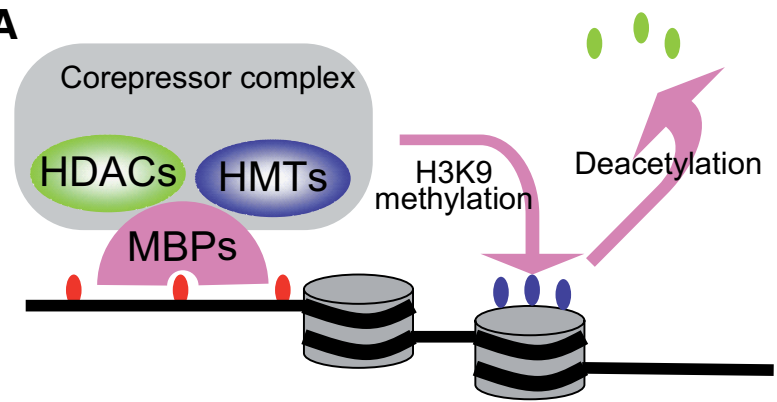

B

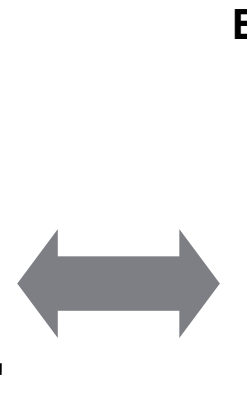

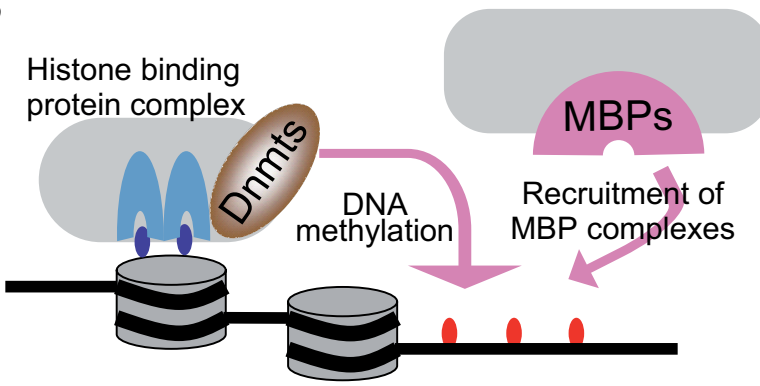

Fig. 2. Interplay between DNA methylation and histone modifications. (A) A model for histone modifications directed by DNA methylation. Methyl-CpG binding proteins recognize methylated DNA and then recruit corepressor complexes including histone deacetylases or methyltransferases to form heterochromatin, characterized by histone hypoacetylation and H3K9 methylation. (B) A model for histone modification-directed DNA methylation. The protein complex including the histone-binding proteins recruits DNA methyltransferases to methylate DNA, resulting in the binding of MBP complexes. These two mechanisms are interconnected and contribute to establish and maintain the transcriptionally silenced chromatin structure.

domain in complex with methylated DNA has been determined (Ohki et al., 2001), and nothing in the structural model seemed to indicate that the MBD proteins would recognize DNA elements besides the methylated $\mathrm{CpG}$. In other words, it seemed that the MBD proteins would bind to all methylated DNA loci irrespective of the sequence context. However, Adrian Bird and coworkers found by a modified site-selection assay that MeCP2 does have a preference for targets in which the methylated bases are surrounded by $A / T$ rich sequences (Klose et al., 2005). This opened the possibility that other MBD proteins might also bind preferentially to certain methylated targets because of the sequence flanking the methylated CpGs. Interestingly, domains other than the MBD could be involved in this sequence discrimination. For instance, MBD1 has a CXXC zinc finger-like domain that directs it towards some unmethylated CpGs (Jorgensen et al., 2004). Also, the MBD proteins might be recruited to specific target regions by interaction with other proteins that bind DNA in a sequence-specific manner. For example MBD2 interacts with
MIZF, which itself recognizes a consensus DNA sequence (Sekimata and Homma, 2004).

As the correlation between DNA methylation and gene silencing had long been known, it was satisfying to observe that MeCP2, MBD1 and MBD2 were transcriptional repressors (Nan et al., 1997, $\mathrm{Ng}$ et al., 1999, $\mathrm{Ng}$ et al., 2000). An important discovery was that DNA methylation and histone modifications are strongly interconnected (Fig. 2). Indeed, the MBD proteins were found to recruit corepressors that regulate gene expression by acting on histones. These corepressors include histone deacetylases, methyltransferases, and chromatin remodeling factors. Each MBD interacts with several different coregulators, but it is not always clear if all cofactors act simultaneously in a complex, or at different times, or in different situations. For instance, MeCP2 interacts with the Sin3A/HDAC complex, the nucleosome remodeler ATRX, and also associates with an H3K9 methyltransferase activity (Jones et al., 1998, Nan et al., 1998, Fuks et al., 2003, Nan et al., 2007). MBD2 associates with the

TABLE 1

\section{DISTRIBUTION OF DNA METHYLTRANSFERASES AND METHYL-CPG BINDING PROTEINS IN VARIOUS ORGANISMS}

\begin{tabular}{|c|c|c|c|c|c|c|c|c|}
\hline Organism & $\begin{array}{c}\text { DNA } \\
\text { methylation }\end{array}$ & DNMT1 & DNMT3 & Kaiso & ZBTB4 & ZBTB38 & UHRF1 & UHRF2 \\
\hline Homo sapiens & +++1 & Yes $^{2}$ & Yes & NP_006768 & NP_065950 & NP_001073881 & NP_001041666 & NP_690856 \\
\hline Mus musculus & +++ & Yes & Yes & NP_064652 & NP_083624 & NP_780746 & NP_035061 & NP_659122 \\
\hline Gallus gallus & +++ & Yes & Yes & NP_001073197 & $N D^{3}$ & XP_422601 & XP_418269 & $\begin{array}{c}\text { ENSGALP } \\
00000024227\end{array}$ \\
\hline Xenopus tropicalis & +++ & Yes & Yes & $\begin{array}{c}\text { ENSXETP } \\
00000009735\end{array}$ & ND & $\begin{array}{c}\text { ENSXETP } \\
00000056313\end{array}$ & $\begin{array}{c}\text { ENSXETP } \\
00000048273\end{array}$ & $\begin{array}{c}\text { ENSXETP } \\
00000001255\end{array}$ \\
\hline Takifugu rubripes & +++ & Yes & Yes & $\begin{array}{c}\text { SINFRUP } \\
00000177461\end{array}$ & ND & $\begin{array}{c}\text { SINFRUP } \\
00000158875\end{array}$ & $\begin{array}{c}\text { SINFRUP } \\
00000162015\end{array}$ & $\begin{array}{c}\text { SINFRUP } \\
00000155873\end{array}$ \\
\hline Danio rerio & +++ & Yes & Yes & ABI97385 & ND & $\begin{array}{c}\text { GENSCAN } \\
00000008127 / \\
\text { XP_001339146 }\end{array}$ & \multicolumn{2}{|c|}{ NP_998242 } \\
\hline Ciona intestinalis & ++ & Yes & Yes & ND & ND & ND & \multicolumn{2}{|c|}{ NP_001071846 } \\
\hline Apis mellifera & + & Yes & Yes & ND & ND & ND & \multicolumn{2}{|c|}{ XP_001120707 } \\
\hline Drosophila melanogaster & $+^{5}$ & No & No & ND & ND & ND & \multicolumn{2}{|c|}{ ND } \\
\hline Caenorhabditis elegans & - & No & No & ND & ND & ND & \multicolumn{2}{|c|}{ ND } \\
\hline Arabidopsis thaliana & ++ & Yes & Yes & ND & ND & ND & \multicolumn{2}{|c|}{ NP_176091/NP_176779/NP_1987716 } \\
\hline
\end{tabular}

Representative accession numbers obtained from the GenBank or Ensembl databases are indicated.

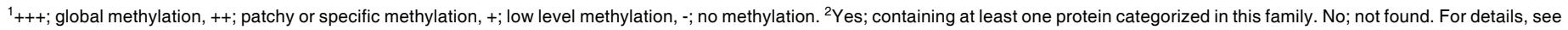

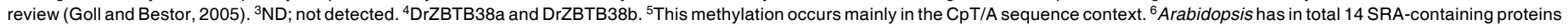
including these three. 
NuRD corepressor complex (Zhang et al., 1999), and MBD1 with the H3-K9 histone methyltransferases SETDB1 and SUV39H1, and the heterochromatin-binding protein HP1 (Fujita et al., 2003, Sarraf and Stancheva, 2004). Recent studies showed that MBD4 also acts as a transcriptional repressor by associating with the Sin3A/HDAC complex (Kondo et al., 2005).

\section{The MBD proteins: dispensable or redundant?}

Given the importance of DNA methylation during embryonic development (Li et al., 1992, Okano et al., 1999), it was a surprise to find out that not a single gene of the MBD family is essential (Table 2). MeCP2, MBD1 and MBD2 have been knocked out in mice, and the mutant animals display only mild phenotypes (see below) (Chen et al., 2001, Guy et al., 2001, Hendrich et al., 2001, Zhao et al., 2003). Why do the phenotypes of MBD-knockout mice differ from those of Dnmt mutants? One possible explanation is that the MBD genes are functionally redundant and can compensate for the deletion of each other. However, the combined knockout of $M B D 2$ and $M e C P 2$ does not enhance either phenotype (Guy et al., 2001), indicating that these two genes are not functionally overlapping. Along the same lines, the proteins MBD1, MBD2, and MeCP2 bind different loci in cultured human cells (Ballestar et al., 2003, Klose et al., 2005), suggesting that the proteins have different functions and may not be redundant. The generation of a triple $M e C P 2 / M B D 1 / M B D 2$ knockout is needed to establish if it is indeed the case.

Another explanation for the viability of MBD-knockout mice is that DNA methylation in itself might be sufficient to silence genes by inhibiting the binding of transcriptional activators. The MBD proteins could be required not for the initiation of repression, but only for its maintenance, and have only subtle effects. It is also possible that non-MBD proteins including Zinc finger or SRAcontaining proteins are important in the recognition of methylated DNA during early development.

\section{Subtle roles for MBD1 and MBD2 in the regulation of gene expression}

Even though they are not essential for viability, the MBD proteins do have some important roles in other specific contexts. MBD1 is likely to be involved in the maintenance of genome stability. MBD1 knockout mice show increased genomic instability and elevated expression of the repeated element IAP (Zhao et al., 2003). Moreover, MBD1 interacts with methylpurine-DNA glycosylase (MPG), which excises damaged bases from substrate DNA, and repairs the base damage in heterochromatic region (Watanabe et al., 2003). These findings raise the possibility that MBD1 links genome maintenance with transcriptionally silenced chromatin structure.

$M B D 2-n u l l$ mice are more resistant than wild-type to intestinal tumorigenesis when crossed with the $A P C^{M i n /+}$ mouse, a model for human familial adenomatous polyposis (Sansom et al., 2003). This indicates that MBD2 is necessary for tumor formation, presumably because it represses some methylated tumor-suppressor genes. Interestingly, MBD2 was shown to be abundant in the colon and repress the expression of exocrine pancreatic genes that are not necessary for colon function in a DNAmethylation dependent manner (Berger et al., 2007). MBD2
TABLE 2

\section{KNOCKOUT PHENOTYPES OF MBP GENES IN THE MOUSE}

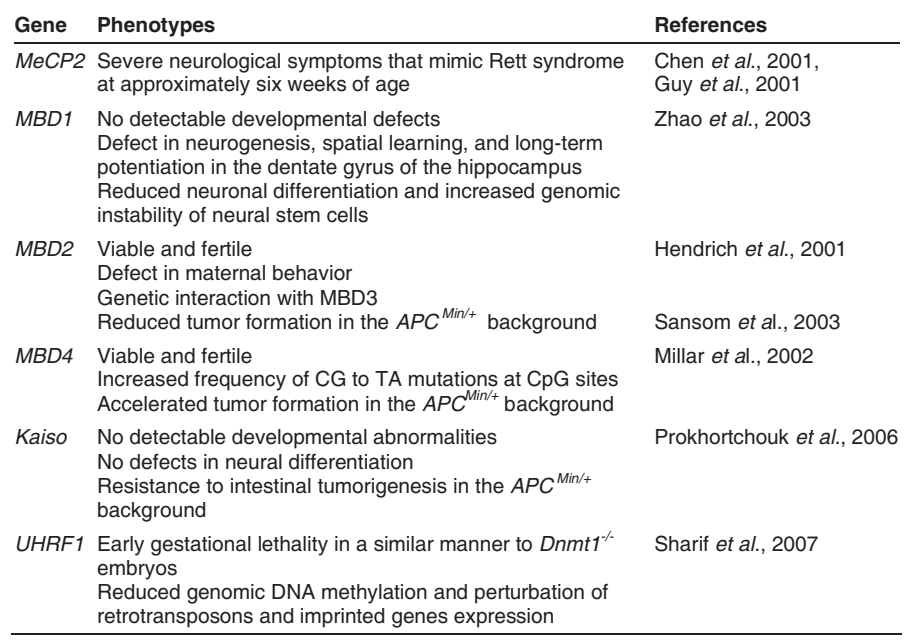

knockout mice also show a maternal behavioral defect (Hendrich et al., 2001). The reason for this is unknown, but could be linked to the existence of many genes undergoing imprinted expression in the brain, and that might influence behavior (Davies et al., 2005). MBD2 is also involved in the regulation of the interleukin4 gene during the differentiation of T-helper cells into Th2-helper cells (Hutchins et al., 2002). In addition, several other genes are likely to be regulated by MBD2. A recent study indicated that MBD2 is involved in the repression of the methylated Xist gene on the active X-chromosome (Barr et al., 2007).

\section{Functions of the MBD proteins in the nervous system}

DNA methylation is important for neurogenesis. One wellestablished case is that it regulates the timing of astrocyte differentiation (Kondo, 2006). For example, methylation in the CpG site within the STAT3-binding sequence located in the GFAP promoter is a critical determinant for astrocyte differentiation in the fetal brain (Takizawa et al., 2001). Correspondingly, the MBD proteins appear to play important roles in the brain. MBD1 is highly expressed in the hippocampus and a subpopulation of immature cells, and MBD1-deficient neural stem cells show reduced neuronal differentiation (Zhao et al., 2003). MBD1 knockout ES cells or mice display decreased neurogenesis and deficits in spatial learning and dentate gyrus-specific long-term potentiation. Although the precise molecular mechanism by which MBD1 regulates these pathways is still unclear, MBD1 appears to play important roles in the epigenetic regulation in the function of Central Nervous System (CNS).

Mutations in the MeCP2 gene are associated with Rett syndrome, an X-linked human neurological disorder that occurs almost exclusively in females (Amir et al., 1999). The MeCP2 mutant mouse also shows similar phenotypes (Chen et al., 2001, Guy et al., 2001), indicating that MeCP2-deficient mouse is a model system for human Rett syndrome. As MeCP2 functions as a transcriptional repressor, it is considered that expression levels of specific target genes of MeCP2 are impaired in the patients of 
Rett syndrome or MeCP2-null mice. Although initial experiment by microarray analysis with wild type and $M e C P 2$ knockout brains failed to detect global changes of gene expression (Tudor et al., 2002), recent studies identified several candidate MeCP2 target genes (Kriaucionis et al., 2006; Chahrour et al., 2008). Importantly, one of the target genes of MeCP2 is the neurotrophic factor $B D N F$, which is repressed by the MeCP2/Sin3A complex but activated by $\mathrm{Ca}^{2+}$ signaling (Chen et al., 2003, Martinowich et al., 2003). MeCP2 is also involved in the regulation of neuronal genes by cooperating with REST (Ballas et al., 2005) and of the imprinted genes DIx5 and DIx6 (Horike et al., 2005). Recently, a brain-specific micro RNA, miR-184, was shown to be regulated by MeCP2 (Nomura et al., 2008). However, the mechanism of target gene regulation by MeCP2 is still not fully understood, and it could act by mechanisms other than the repression of transcriptional initiation (Bienvenu and Chelly, 2006). Indeed MeCP2 regulates splicing by interacting with the RNA-binding protein YB1 (Young et al., 2005). Furthermore, a genome-wide analysis with ChIP-onchip technology in the neuroblastoma cells identified MeCP2 binding sites exclusively in expressed genes, but not in repressed genes as was expected (Yasui et al., 2007). Further analysis is required to understand the role of MeCP2 in Rett syndrome. A recent interesting discovery in the field is that the phenotype caused by lack of MeCP2 is reversible if the protein is supplied back to mutant neurons (Guy et al., 2007).

\section{Methyl-CpG binding proteins of the Zinc finger family}

Three proteins are known to recognize methyl-CpG via zinc fingers: Kaiso, ZBTB4 and ZBTB38.

Kaiso was originally identified by yeast two-hybrid screening in a search for proteins that interact with the p120 catenin (Daniel and Reynolds, 1999). Kaiso contains three tandem zinc fingers at the $\mathrm{C}$ terminus and a BTB domain at the $\mathrm{N}$ terminus (Fig. 1). As p120 catenin is similar to the cell adhesion cofactors $\beta$-catenin and plakoglobin, Kaiso is speculated to be a downstream effector of $\beta$-catenin and p120 catenin signaling (van Roy and McCrea, 2005). Kaiso was also independently identified as a component of a protein complex that binds to a region of the mouse S100A4 gene in a methylation-dependent manner (Prokhortchouk et al., 2001). Whereas MBD proteins recognize a single methylated $\mathrm{CpG}$, Kaiso requires two consecutive symmetrically methylated CpG sequences for optimal binding. Kaiso was also biochemically identified from HeLa cell nuclear extracts as a component of the NCoR corepressor complex including HDAC3, GPS2 and TBL1/TBLR1 (Yoon et al., 2003). Kaiso directly binds to NCoR via its BTB domain; this type of interaction with corepressors involving the BTB is a common feature of BTB-zinc finger transcription factors (Collins et al., 2001). Kaiso recruits the NCoR complex to the MTA2 promoter in a DNA methylation-dependent manner, resulting in hypoacetylation and methylation at $\mathrm{K} 9$ of $\mathrm{H} 3$ at the promoter region (Yoon et al., 2003). Therefore, this establishes that Kaiso is a DNA methylation-dependent transcriptional repressor of the MTA2 gene (Fig. 3). However, as the cultured cells do not reflect the normal patterns of DNA methylation, it remains unknown whether MTA2 is an actual target of Kaiso in normal cells and at present there is no information about methylated target genes of Kaiso in normal cells.

The human genome encodes two proteins that have Kaiso-like Zinc fingers: ZBTB4 and ZBTB38 (Filion et al., 2006). Both proteins contain a BTB domain, and they are longer and more complex than Kaiso, notably because they have additional Zinc fingers (Fig. 1). These two proteins were shown, like Kaiso, to bind methylated DNA thanks to their three Kaiso-like Zinc fingers. However, in contrast to Kaiso, they can bind to a single methylated CpG sequence. ZBTB4 and ZBTB38 repress transcription of methylated promoters in a reporter assay, and localize to densely methylated pericentromeric heterochromatin regions in mouse cells in a DNA methylation-dependent manner. All these findings support the idea that ZBTB4 and ZBTB38 are bona fide methylCpG-binding proteins. As for Kaiso, however, their target genes in normal cells are unknown at this point.

\section{Bimodal DNA binding activity of Kaiso and ZBTB4}

In addition to binding methylated DNA, Kaiso was shown by a site-selection strategy to bind with high affinity to the DNA sequence TCCTGCNA, which is not methylated. This sequence has been named Kaiso-binding sequence or KBS (Daniel et al., 2002). $\mathrm{A} K B S$ is present in the promoter of matrilysin, a target of the Wnt/ beta-catenin/TCF. It is bound by Kaiso, which seems to repress its transcription in vivo (Fig. 3) (Spring et al., 2005). In addition, Kaiso binds to the $5^{\prime}$ beta-globin insulator that contains the KBS in vivo (Defossez et al., 2005). ZBTB4 also can bind to the KBS, at least in vitro, but ZBTB38 cannot (Filion et al., 2006). Of course the Kaiso-like zinc fingers of ZBTB38 may bind a different unmethylated consensus sequence that is unknown.

How do the same three Zinc fingers direct Kaiso (and ZBTB4) to methylated DNA or to unmethylated consensus sequences? Our detailed sequence analysis shows that the third finger is the least evolutionarily conserved, whereas the first and second fingers show high homology among Kaiso, ZBTB4 and ZBTB38

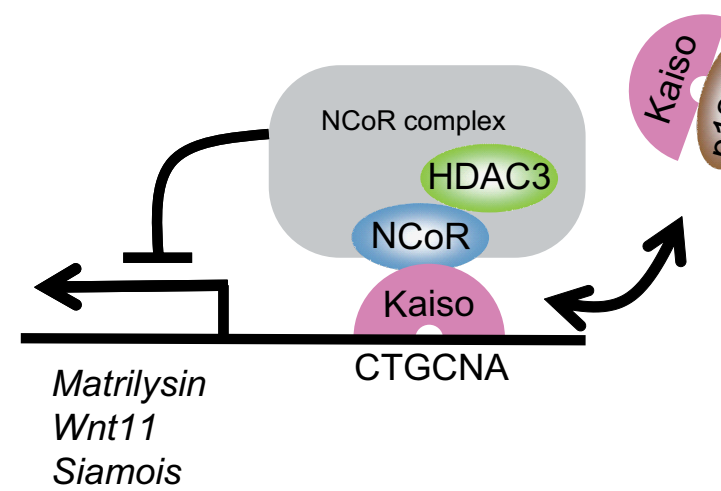

Fig. 3. Mechanisms of Kaisomediated transcriptional repression. Kaiso binds to the KBS of target promoters and represses their transcription by recruiting a corepressor complex including HDAC3 and NCOR (left). Kaiso also represses methylated promoters via recruitment of the NCoR complex (right). The binding of Kaiso to these sequences is inhibited by direct interaction of p120 catenin with the zinc finger region of Kaiso. 
A

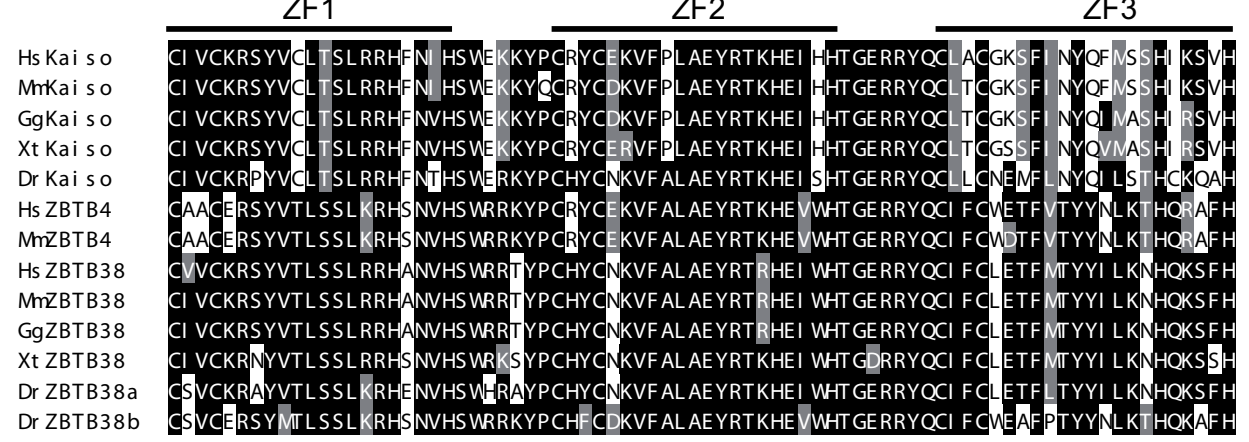

Fig. 4. Evolutionarily conserved methyl-CpG-binding zinc fingers. (A) Multiple alignments of methyl$C p G$ binding zinc fingers of Kaiso, ZBTB4 and ZBTB38 from human (Homo sapiens), mouse (Mus musculus), chicken (Gallus gallus), frog (Xenopus tropicalis) and zebrafish (Danio rerio). We searched for proteins that contain three methyl-binding zinc finger motifs in the NCBI and Ensembl databases. Based on their structure and sequences, the proteins were classified as orthologs of Kaiso, ZBTB4 or ZBTB38. The alignment was performed using the Clustal Walgorithm. (B) The domain structures of human (HsZBTB38) and two zebrafish ZBTB38 proteins (DrZBTB38a and DrZBTB38b). The methyl-binding zinc fingers are indicated by bold lines.

B

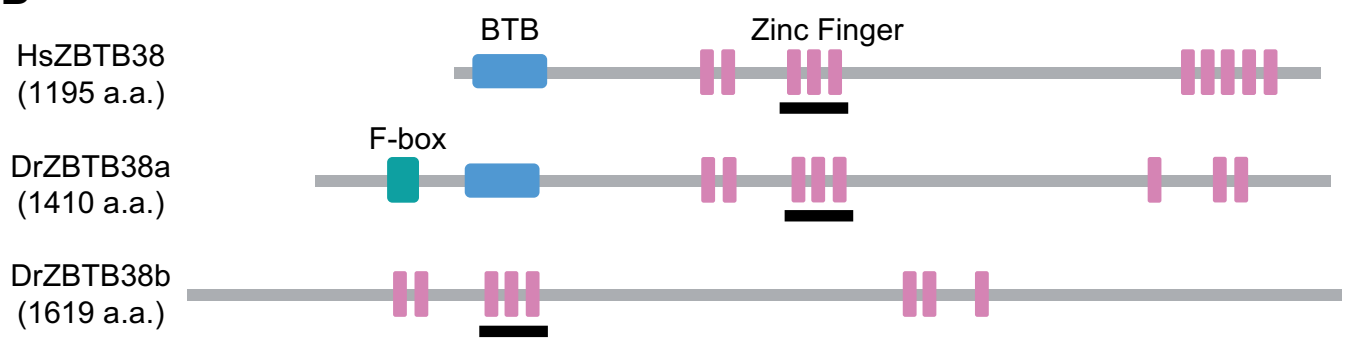

from various species in vertebrates (Fig. 4). It suggests that these two fingers play important roles in the recognition of DNA, yet it could also be that they are involved in the interaction with partner proteins. Although Kaiso, ZBTB4, and ZBTB38 have been shown to bind to various methylated probes in vitro (Prokhortchouk et al., 2001, Filion et al., 2006), it is unknown whether their binding is influenced by the sequences flanking the methylated CpGs, as is the case of MeCP2 (Klose et al., 2005).

\section{Mechanism of transcriptional repression by Kaiso-like proteins}

Kaiso represses transcription by recruiting the NCoR complex, but ZBTB4 and ZBTB38 behave differently. ZBTB38 is likely to recruit a complex containing the corepressor protein CtBP: the mouse ortholog of ZBTB38 interacts with the two closely related proteins CtBP1 and CtBP2 and recruits them to the densely methylated pericentromeric heterochromatin (Sasai et al., 2005). $\mathrm{CtBP}$ is involved in the repression of epithelial and proapoptotic genes and knockdown of CtBP results in apoptosis in a p53independent manner (Grooteclaes et al., 2003, Zhang et al., 2003). Furthermore, CtBP1 and CtBP2 have overlapping and unique roles during development and knockout of both genes results in embryonic lethality (Hildebrand and Soriano, 2002). CtBP associates with many transcription factors and cofactors (Chinnadurai, 2002), and ZBTB38 may be one of them. The CtBP complex includes histone deacetylases, methyltransferases and a demethylase (Shi et al., 2003), and it is quite possible that ZBTB38 recruits these enzymes to repress methylated target genes.

ZBTB4 is also a transcriptional repressor, but its mode of action is unknown and likely be different from that of Kaiso or ZBTB38. Indeed, we found that the CtBP-interaction motifs found in ZBTB38 do not exist in ZBTB4. And the BTB domain, which is important for repression by Kaiso, is not required for repression by ZBTB4
(Filion et al., 2006). In fact, the BTB domain of ZBTB4 is disrupted by a long serine-rich insertion and might have lost its repressive function (Perez-Torrado et al., 2006). Recently, ZBTB4 was shown to associate with the Sin3/HDAC complex to repress the p21 promoter, although the repression is not dependent on binding to methylated DNA (Weber et al., 2008).

\section{Kaiso is essential for amphibian development}

The Xenopus genome encodes a Kaiso homolog, xKaiso (Kim et al., 2002). Depletion of xKaiso by morpholino oligos results in embryonic lethality with failure of gastrulation, premature activation of zygotic genes before the mid-blastula transition, and apoptosis (Kim et al., 2004, Ruzov et al., 2004). xKaiso has been proposed to repress several genes in the Wnt pathway that contain KBSs in their promoters (Wnt11 (Kim et al., 2004), Siamois, c-Fos, Cyclin-D1, and c-Myc (Park etal., 2005)), and this could explain this effect. Interestingly, however, the xKaiso knockdown phenotypes are quite similar to those of hypomethylated embryos in which the DNA methyltransferase xDnmt 1 is depleted (Stancheva and Meehan, 2000, Stancheva et al., 2001). However, DNMT1 seems to have multifunctional non-enzymatic roles in development and recent report shows that XDNMT1 functions as a transcriptional repressor independent of its catalytic activity during early development (Dunican et al., 2008). Nevertheless, Richard Meehan and coworkers showed very recently that the phenotypes of xKaiso-depletion were rescued by zebrafish Kaiso, which binds to methylated DNA but not to the KBS (Ruzov et al., 2009b). These findings suggest that the KBS-binding function of Kaiso is not required for Xenopus development.

\section{Functional redundancy among Kaiso family proteins?}

Given the possible involvement of Kaiso in repressing genes in the Wnt pathway, and the importance of xKaiso in amphibians, 
mouse Kaiso was expected to be important for embryonic development. However, surprisingly, the knockout of mouse Kaiso caused no overt phenotype (Table 2) (Prokhortchouk et al., 2006). The expression of proposed Kaiso target genes such as MTA2, S100A4 and Wnt11 was also unaltered in kaiso-deficient mouse tissues.

Why does Kaiso deficiency have different outcomes in Xenopus and in mouse? One possible explanation is that the roles of DNA methylation in controlling the zygotic gene program are different between mice and frogs (Prokhortchouk et al., 2006). This is also suggested in the case of MeCP2, which is not essential for embryonic development in mouse (Chen et al., 2001, Guy et al., 2001), but regulates expression of Hairy2a in Xenopus. Accordingly, depletion of MeCP2 in Xenopus results in severe defects in neurogenesis during development (Stancheva et al., 2003). In addition, it is also important to note the possibility that Kaiso is functionally overlapping with ZBTB4 and ZBTB38 or with MBD family proteins. A recent study indicated that Kaiso, MBD2 and MeCP2 are not redundant during embryogenesis, but have an overlapping function in neural differentiation (Martin Caballero et al., 2009). Given the similar DNA binding properties of Kaiso and ZBTB4, these two proteins may be functionally redundant (Filion et al., 2006). ZBTB4 may be the factor that rescues Kaiso deficiency in mouse, the absence of a ZBTB4 counterpart in $X e n o p u s$ would also explain the presence of a phenotype in frogs.

Although the expression patterns of Kaiso, ZBTB4 and ZBTB38 are overlapping in several adult mouse tissues (Daniel and Reynolds, 1999, Sasai et al., 2005, Filion et al., 2006), the degree of redundancy between Kaiso, ZBTB4, and ZBTB38, is unknown and will only be clarified after the generation of mutant mice for all three genes. At present, the most likely prediction is that the genes have some overlapping, and some non-overlapping functions. Firstly, p120 catenin seems to regulate Kaiso: the Kaisop120 catenin interaction abolishes binding of Kaiso to DNA (either methylated or not) and inhibits its repressive action (Daniel et al., 2002, Kelly et al., 2004). ZBTB4 and ZBTB38, in contrast to Kaiso, do not interact with p120 catenin (Filion et al., 2006). Therefore, ZBTB4 and ZBTB38 are not likely to be involved in catenin signaling. A second difference between Kaiso and ZBTB4/ZBTB38 is their cellular distribution: in transfected mouse fibroblasts ZBTB4 and ZBTB38 primarily localize to pericentromeric heterochromatin whereas Kaiso shows a diffuse nuclear abundance pattern (Filion et al., 2006). Thirdly, the BTB domain of Kaiso is known to homodimerize (Daniel and Reynolds, 1999), whereas ZBTB4 and ZBTB38 cannot homodimerize via the BTB domains, but homodimerize or heterodimerize each other via zinc fingers (Kiefer et al., 2005, Filion et al., 2006). To better understand the functional differences among Kaiso family proteins, it would be useful to determine whether all three proteins bind the same target sites, or have different binding preferences.

\section{Evolution of Kaiso family proteins: ZBTB4 is restricted to mammals}

Our searches in genome databases show that Kaiso-related proteins are identifiable in vertebrates, but not in invertebrates such as Ciona intestinalis and in plants, even though these species contain methylated DNA (Table 1). This indicates that the Kaiso family has a vertebrate-specific role. Kaiso and ZBTB38 are found in all vertebrate genomes from zebrafish (Danio rerio) to humans, whereas ZBTB4 is found in mammals but not in zebrafish, Xenopus or chicken (Gallus gallus) (Table 1). This suggests the following sequence of events: Kaiso and ZBTB38 arose from a common ancestor gene at some point close to the invertebratevertebrate transition. $Z B T B 4$ was then generated by duplication of the ZBTB38 gene at some later time (Filion et al., 2006).

The genomes of zebrafish, medaka (Oryzias latipes) and stickleback (Gasterosteus aculeatus) contain two ZBTB38-like genes, DrZBTB38a and DrZBTB38b. DrZBTB38b lacks the BTB domain, but shows overall similarity to ZBTB38 than to ZBTB4, suggesting that this gene was generated by duplication of DrZBTB38a (Fig. 4). This duplication is specific to just some species of fish as Fugu (Takifugu rubripes) and Tetraodon nigroviridis contain only one ZBTB38gene, like Xenopus tropicalis and Xenopus laevis. Interestingly, this is reminiscent of $M B D 3$, for which two related genes are found in zebrafish and Fugu, but only one in mammals (Hendrich and Tweedie, 2003). Because we do not precisely know which amino-acids are important for binding DNA, it is not yet possible to predict if the Kaiso-like proteins in lower vertebrates bind the KBS, or methylated DNA, or both, or neither. As for Kaiso, it seems that the methyl-binding activity is evolutionarily conserved, whereas the KBS-binding activity varies between species (Ruzov et al., 2009).

\section{SRA proteins: essential proteins for the maintenance of DNA methylation}

The third class of methyl-CpG binding factors are UHRF1 (also called Np95, and ICBP90) and the related protein UHRF2 (also called NIRF). In these proteins the SRA domain (SET and Ring finger-associated) is responsible for methyl-CpG binding. They also contain a ubiquitin-like domain, a Ring finger motif and a PHD finger (Fig. 1). UHRF1 was initially identified as a protein that binds to a CCAAT box in the promoter of the topoisomerase $/ 1 \alpha$ gene (Hopfner et al., 2000). However, UHRF1 and UHRF2 were subsequently shown to bind with higher affinity to methylated DNA than to the CCAAT box (Unoki et al., 2004). UHRF1 is involved in the regulation of the cell cycle and DNA damage control (Bonapace et al., 2002, Muto et al., 2002), and regulates cell proliferation by repressing methylated tumor suppressor genes via recruitment of the HDAC complex to the promoters (Unoki et al., 2004). UHRF1 colocalizes with replication foci in mid-to late $S$ phase and is required for proper heterochromatin formation in mammalian cells (Papait et al., 2007). Since the Ring finger of UHRF1 functions as an E3 ubiquitin ligase for histone $\mathrm{H} 3$ (Citterio et al., 2004), UHRF1 was supposed to translate DNA methylation into histone modifications.

Recently, two groups clearly demonstrated that UHRF1 mediates epigenetic inheritance of DNA methylation (Bostick et al., 2007, Sharif et al., 2007). UHRF1 associates with DNMT1 and PCNA at replicating heterochromatic regions. As UHRF1 has preferential binding affinity for hemi-methylated DNA over fully methylated DNA (Bostick et al., 2007), DNMT1 is specifically recruited to hemi-methylated sites by UHRF1 during DNA replication. UHRF1 knockout mice die during early embryogenesis just like Dnmt1 mutants (Table 2) (Sharif et al., 2007). Furthermore, in UHRF1-deficient mouse and ES cells, methylation of imprinted genes and satellite repeats are decreased. All in all, UHRF1 is 
A

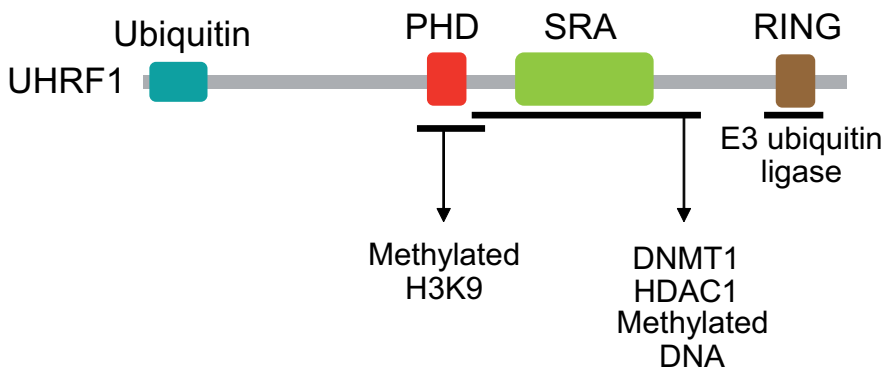

B

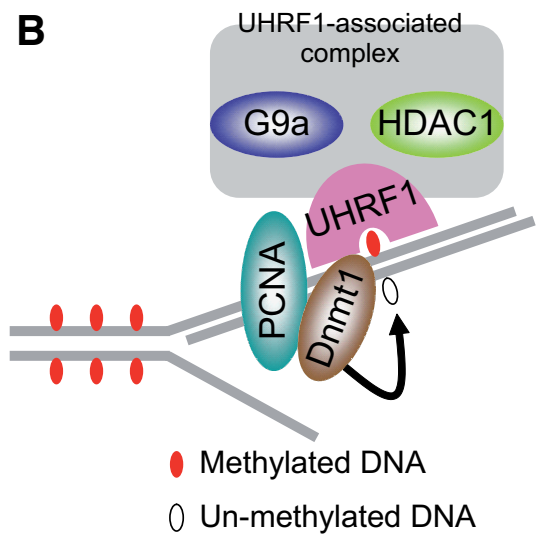

Fig. 5. Functions of UHRF1 during DNA replication. (A) Schematic representation of UHRF1. UHRF1 binds to methylated DNA as well as DNMT1 and HDAC1 via the region including the SRA domain. The PHD finger binds to methylated K9 of H3 and the Ring finger functions as an E3 ubiquitin ligase. (B) A model for the maintenance of DNA methylation by the UHRF1-DNMT1 complex during DNA replication. UHRF1 binds to hemi-methylated DNA at the replication foci and recruits DNMT1 to maintain the DNA methylation status. UHRF1 is also likely to ensure the heritability of histone modification by recruiting the G9a-containing complex.

considered very important for the targeting of DNMT1 to hemimethylated DNA, in order to ensure that DNA becomes remethylated after replication (Fig. 5). In addition, since the UHRF1 complex contains G9a histone methyltransferase and the PHD finger of UHRF1 binds to methylated $\mathrm{K} 9$ of $\mathrm{H3}$ (Sharif et al., 2007, Karagianni et al., 2008), UHRF1 may be important for the maintenance of histone marks as well. Furthermore, the crystal structure of the SRA domain of UHRF1 bound to hemi-methylated DNA revealed that the SRA domain recognizes methylated DNA by flipping methyl-cytosine out of the DNA helix (Arita et al., 2008; Avvakumov et al., 2008; Hashimoto et al., 2008), which is quite distinct from the recognition of symmetrically methylated DNA by the MBD domain (Ho et al., 2008). These studies answered the important question of why DNMT1 has an innate capacity to recognize hemimethylated DNA (Jeltsch, 2006). However, it remains unknown whether UHRF1 is required for maintaining DNA methylation over the whole genome, or just at some specific regions. Also, does the related protein UHRF2 play a similar role?

At any rate, the situation of UHRF1 is reminiscent of MBD1, which associates with the p150 subunit of CAF-1 and PCNA during S-phase and maintain H3-K9 methylation via recruitment of the histone methyltransferase SETDB1 to methylated DNA (Sarraf and Stancheva, 2004). It would be interesting to see whether the MBD1 complex acts simultaneously with the SRA proteins or whether it functions independently. Other unknown factors might be also involved in maintaining DNA methylation. For instance, the SWI/SNF chromatin remodeling factor Lsh, and CGBP, a protein that binds non-methylated $\mathrm{CpG}$, are known to be required for global methylation of the genome (Dennis et al., 2001, Carlone et al., 2005). These findings suggest that the initiation, recognition, and maintenance of DNA methylation is complex, and that additional players may remain to be discovered.

\section{Roles of methyl-CpG binding proteins in invertebrates and in plants}

MBD genes exist not only in vertebrates, but also in invertebrates and in plants, and $M B D 2 / M B D 3$ is thought to be the ancestor of the MBD genes (Hendrich and Tweedie, 2003).
Drosophila contains only one MBD protein (dMBD2/3) and one DNA methyltransferase (dDnmt2) and its genome is methylated at CpT/A sequences, which are recognized by dMBD2/3 (Kunert et al., 2003, Marhold et al., 2004). These two proteins are not essential for development: flies lacking these genes are viable and fertile. Caenorhabditis elegans has an MBD-like gene, even though its genome is unmethylated. Interestingly, the MBD-like protein in $C$. elegans plays important roles in development, suggesting that CeMBD has functions other than binding methylated DNA (Gutierrez and Sommer, 2004). Similarly, mammalian MBD3 does not bind methylated DNA, yet it is essential for development and plays important roles in pluripotency of ES cells (Hendrich et al., 2001, Kaji et al., 2006). The genome of Arabidopsis thaliana contains 13 genes for MBD-containing proteins (Zemach and Grafi, 2007), of which at least three can bind methylated DNA. Some, like AtMBD9 and AtMBD11, are not functional as methylCpG binding proteins but are nevertheless important for plant development. Furthermore, vertebrate and invertebrate genomes contain a number of MBD-like domains, called TAM (TIP5, ARBP, $\underline{M B D}$ ), most of which are predicted to be non-functional for binding to methyl-CpG (Hendrich and Tweedie, 2003). It seems that these MBD-like domains have lost methyl-binding capacity as they were gaining new functions during evolution.

Like the MBD proteins, the SRA proteins are found in various invertebrate genomes including that of the social insect honeybee (Apis mellifera), as well as in plant genomes, suggesting that they may regulate DNA methylation in these species (Table 1). At least 14 SRA-containing proteins are found in Arabidopsis, and other plants also contain many SRA proteins. Like mammalian SRAcontaining proteins, the Arabidopsis SRA proteins Vim1 and KRYPTONITE (KYP) bind to methylated DNA via the SRA domain (Johnson et al., 2007, Woo et al., 2007). The high number of SRA proteins in plants might result from the complexity of DNA methylation in plants where not only $\mathrm{CpG}$, but also $\mathrm{CpHpG}$ (where $\mathrm{H}=$ $\mathrm{A}, \mathrm{T}$ or $\mathrm{C}$ ) and $\mathrm{CpHpH}$ sequences can be methylated. Indeed, Vim1 can bind to methylated $\mathrm{CpHpG}$ sequence as well as methylated $\mathrm{CpG}$, whereas KYP binds to methylated $\mathrm{CpG}, \mathrm{CpHpG}$ and $\mathrm{CpHpH}$ sequences. Although it remains to be tested whether this binding preference is also shown on the hemi-methylated DNA, 
the plant SRA proteins might have evolved the ability to bind to different methylated sequences. Alternatively, it is possible that some of the plant SRA proteins are not methyl-CpG binding proteins, but have important functions in histone modifications or other types of chromatin regulation. Indeed, some SRA proteins in plants have a SET domain that may function as a histone methyltransferase (Baumbusch et al., 2001).

Interestingly, the honeybee contains methylated DNA in the context of $\mathrm{CpG}$ sequence, as well as MBD proteins, SRA proteins, and maintenance and de novo methyltransferases (Wang et al., 2006). This is in sharp contrast to Drosophila and C. elegans that lack de novo and maintenance DNA methyltransferases and SRA proteins and have lower levels of CpT/A methylation or no DNA methylation, respectively (Table 1). These findings imply that de novo/maintenance DNMTs and SRA proteins may have coevolved to ensure the faithful maintenance of DNA methylation.

\section{Are there additional methyl-CpG binding proteins?}

Considering that DNA methylation has a wide variety of roles in mammalian genomes, DNA methylation might be interpreted by not just three families of proteins. The zinc finger is one of the most common motifs in the mammalian genome. Although the Kaiso-like zinc finger motif is'found in only three proteins Kaiso, ZBTB4 and ZBTB38, it is conceivable that additional proteins might also have the ability to bind to methyl-CpG via zinc fingers. Indeed, an artificial zinc finger protein has been shown to bind to methylated DNA (Choo, 1998). Although it is difficult to identify such proteins at the moment, the proteins that localize to densely methylated pericentromeric heterochromatin region, like MBD proteins or Kaiso-like proteins (Hendrich and Bird, 1998, Filion et al., 2006), could be possible candidates. It is also possible that novel methyl-CpG binding proteins (domains) might be discovered, maybe through biochemical approaches, or by structural analyses.

\section{Concluding remarks}

After the discovery that DNA methylation and transcriptional repression are correlated, numerous factors including MBPs, histone modification enzymes, chromatin remodeling factors, DNA methyltransferases and histone binding proteins have been identified and shown to link DNA methylation and transcriptional silencing. However, we are still far from a complete understanding of this complex system and there are many issues to be uncovered. How are these proteins targeted to specific regions? How is the DNA methylation mark erased and re-established during development? The recent advances in genome-wide analysis techniques, the availability of complete genome sequences, and of genetically engineered mice and cell lines will be helpful to overcome these issues. Given the involvement of DNA methylation in development, cancer and human diseases, a greater understanding of the molecular mechanisms of DNA methylation, and of the roles of MBPs, is of great importance for the development of future clinical applications.

\section{Acknowledgements}

NS is supported by a post-doctoral fellowship from the Institut National du Cancer. The laboratory of PAD is funded by Association pour la
Recherche sur le Cancer (Grant 4859), Ligue contre le Cancer, and CNRS (Programme ATIP Plus).

\section{References}

AMIR, R.E., VAN DEN VEYVER, I.B., WAN, M., TRAN, C.Q., FRANCKE, U. and ZOGHBI, H.Y. (1999). Rett syndrome is caused by mutations in X-linked MECP2, encoding methyl-CpG-binding protein 2. Nat Genet 23: 185-188.

ARITA, K., ARIYOSHI, M., TOCHIO, H., NAKAMURA, Y. and SHIRAKAWA, M. (2008). Recognition of hemi-methylated DNA by the SRA protein UHRF1 by a base-flipping mechanism. Nature 455: 818-21.

AVVAKUMOV, G.V., WALKER, J.R., XUE, S., LI, Y., DUAN, S., BRONNER, C., ARROWSMITH, C.H. and DHE-PAGANON, S. (2008). Structural basis for recognition of hemi-methylated DNA by the SRA domain of human UHRF1. Nature 455: 822-5.

BALLAS, N., GRUNSEICH, C., LU, D.D., SPEH, J.C. and MANDEL, G. (2005). REST and its corepressors mediate plasticity of neuronal gene chromatin throughout neurogenesis. Cell 121: 645-657.

BALLESTAR, E., PAZ, M.F., VALLE, L., WEI, S., FRAGA, M.F., ESPADA, J., CIGUDOSA, J.C., HUANG, T.H. and ESTELLER, M. (2003). Methyl-CpG binding proteins identify novel sites of epigenetic inactivation in human cancer. EMBO J 22: 6335-6345.

BARR, H., HERMANN, A., BERGER, J., TSAI, H.H., ADIE, K., PROKHORTCHOUK, A., HENDRICH, B. and BIRD, A. (2007). Mbd2 contributes to DNA methylationdirected repression of the Xist gene. Mol Cell Biol 27: 3750-3757.

BAUMBUSCH, L.O., THORSTENSEN, T., KRAUSS, V., FISCHER, A., NAUMANN, K., ASSALKHOU, R., SCHULZ, I., REUTER, G. and AALEN, R.B. (2001). The Arabidopsis thaliana genome contains at least 29 active genes encoding SET domain proteins that can be assigned to four evolutionarily conserved classes. Nucleic Acids Res 29: 4319-4333.

BELL, A.C. and FELSENFELD, G. (2000). Methylation of a CTCF-dependent boundary controls imprinted expression of the lgf2 gene. Nature 405: 482-485.

BERGER, J., SANSOM, O., CLARKE, A. and BIRD, A. (2007). MBD2 is required for correct spatial gene expression in the gut. Mol Cell Biol 27: 4049-4057.

BESTOR, T.H. (1992). Activation of mammalian DNA methyltransferase by cleavage of a $\mathrm{Zn}$ binding regulatory domain. EMBO J 11: 2611-2617.

BIENVENU, T. and CHELLY, J. (2006). Molecular genetics of Rett syndrome: when DNA methylation goes unrecognized. Nat Rev Genet 7: 415-426.

BIRD, A. (2002). DNA methylation patterns and epigenetic memory. Genes Dev16: 6-21.

BONAPACE, I.M., LATELLA, L., PAPAIT, R., NICASSIO, F., SACCO, A., MUTO, M., CRESCENZI, M. and DI FIORE, P.P. (2002). Np95 is regulated by E1A during mitotic reactivation of terminally differentiated cells and is essential for $S$ phase entry. J Cell Biol 157: 909-914.

BOSTICK, M., KIM, J.K., ESTEVE, P.O., CLARK, A., PRADHAN, S. and JACOBSEN, S.E. (2007). UHRF1 plays a role in maintaining DNA methylation in mammalian cells. Science 317: 1760-1764.

CARLONE, D.L., LEE, J.H., YOUNG, S.R., DOBROTA, E., BUTLER, J.S., RUIZ, J. and SKALNIK, D.G. (2005). Reduced genomic cytosine methylation and defective cellular differentiation in embryonic stem cells lacking $\mathrm{CpG}$ binding protein Mol Cell Biol 25: 4881-4891.

CHAHROUR, M., JUNG, S.Y., SHAW, C., ZHOU, X., WONG, S.T., QIN, J. and ZOGHBI, H.Y. (2008). MeCP2, a key contributor to neurological disease, activates and represses transcription. Science 320: 1224-9.

CHEN, R.Z., AKBARIAN, S., TUDOR, M. and JAENISCH, R. (2001). Deficiency of methyl-CpG binding protein-2 in CNS neurons results in a Rett-like phenotype in mice. Nat Genet 27: 327-331.

CHEN, W.G., CHANG, Q., LIN, Y., MEISSNER, A., WEST, A.E., GRIFFITH, E.C., JAENISCH, R. and GREENBERG, M.E. (2003). Derepression of BDNF transcription involves calcium-dependent phosphorylation of MeCP2. Science 302: 885-889.

CHINNADURAI, G. (2002). CtBP, an unconventional transcriptional corepressor in development and oncogenesis. Mol Cell 9: 213-224.

CHOO, Y. (1998). Recognition of DNA methylation by zinc fingers. Nat Struct Biol 5: $264-265$. 
CITTERIO, E., PAPAIT, R., NICASSIO, F., VECCHI, M., GOMIERO, P., MANTOVANI, R., DI FIORE, P.P. and BONAPACE, I.M. (2004). Np95 is a histone-binding protein endowed with ubiquitin ligase activity. $\mathrm{Mol} \mathrm{Cell} \mathrm{Biol} 24$ : 2526-2535.

COLLINS, T., STONE, J.R. and WILLIAMS, A.J. (2001). All in the family: the BTB/ POZ, KRAB, and SCAN domains. Mol Cell Biol 21: 3609-3615.

COLOT, V. and ROSSIGNOL, J.L. (1999). Eukaryotic DNA methylation as an evolutionary device. Bioessays 21: 402-411.

CROSS, S.H., MEEHAN, R.R., NAN, X. and BIRD, A. (1997). A component of the transcriptional repressor MeCP1 shares a motif with DNA methyltransferase and HRX proteins. Nat Genet 16: 256-259.

DAMELIN, M. and BESTOR, T.H. (2007). Biological functions of DNA methyltransferase 1 require its methyltransferase activity. Mol Cell Biol 27: 3891-3899.

DANIEL, J.M. and REYNOLDS, A.B. (1999). The catenin p120(ctn) interacts with Kaiso, a novel BTB/POZ domain zinc finger transcription factor. Mol Cell Biol 19: 3614-3623.

DANIEL, J.M., SPRING, C.M., CRAWFORD, H.C., REYNOLDS, A.B. and BAIG, A (2002). The p120(ctn)-binding partner Kaiso is a bi-modal DNA-binding protein that recognizes both a sequence-specific consensus and methylated $\mathrm{CpG}$ dinucleotides. Nucleic Acids Res 30: 2911-2919.

DAVIES, W., ISLES, A.R. and WILKINSON, L.S. (2005). Imprinted gene expression in the brain. Neurosci Biobehav Rev 29: 421-430.

DEFOSSEZ, P.A., KELLY, K.F., FILION, G.J., PEREZ-TORRADO, R., MAGDINIER, F., MENONI, H., NORDGAARD, C.L., DANIEL, J.M. and GILSON, E. (2005). The human enhancer blocker CTC-binding factor interacts with the transcription factor Kaiso. J Biol Chem 280: 43017-43023.

DENNIS, K., FAN, T., GEIMAN, T., YAN, Q. and MUEGGE, K. (2001). Lsh, a member of the SNF2 family, is required for genome-wide methylation. Genes Dev 15: 2940-2944.

DUNICAN, D.S., RUZOV, A., HACKETT, J.A. and MEEHAN, R.R. (2008). xDnmt1 regulates transcriptional silencing in pre-MBT Xenopus embryos independently of its catalytic function. Development 135: 1295-1302.

FEINBERG, A.P. (2007). Phenotypic plasticity and the epigenetics of human disease. Nature 447: 433-440.

FILION, G.J., ZHENILO, S., SALOZHIN, S., YAMADA, D., PROKHORTCHOUK, E. and DEFOSSEZ, P.A. (2006). A family of human zinc finger proteins that bind methylated DNA and repress transcription. Mol Cell Biol 26: 169-181.

FUJITA, N., WATANABE, S., ICHIMURA, T., TSURUZOE, S., SHINKAI, Y., TACHIBANA, M., CHIBA, T. and NAKAO, M. (2003). Methyl-CpG binding domain 1 (MBD1) interacts with the Suv39h1-HP1 heterochromatic complex for DNA methylation-based transcriptional repression. J Biol Chem 278: 2413224138.

FUKS, F. (2005). DNA methylation and histone modifications: teaming up to silence genes. Curr Opin Genet Dev 15: 490-495.

FUKS, F., HURD, P.J., WOLF, D., NAN, X., BIRD, A.P. and KOUZARIDES, T. (2003). The methyl-CpG-binding protein MeCP2 links DNA methylation to histone methylation. J Biol Chem 278: 4035-4040.

GOLL, M.G. and BESTOR, T.H. (2005). Eukaryotic cytosine methyltransferases. Annu Rev Biochem 74: 481-514.

GOLL, M.G., KIRPEKAR, F., MAGGERT, K.A., YODER, J.A., HSIEH, C.L., ZHANG, X., GOLIC, K.G., JACOBSEN, S.E. and BESTOR, T.H. (2006). Methylation of tRNAAsp by the DNA methyltransferase homolog Dnmt2. Science 311: 395398.

GROOTECLAES, M., DEVERAUX, Q., HILDEBRAND, J., ZHANG, Q., GOODMAN, R.H. and FRISCH, S.M. (2003). C-terminal-binding protein corepresses epithelial and proapoptotic gene expression programs. Proc Natl Acad Sci U S A 100: 4568-4573.

GUTIERREZ, A. and SOMMER, R.J. (2004). Evolution of dnmt-2 and mbd-2-like genes in the free-living nematodes Pristionchus pacificus, Caenorhabditis elegans and Caenorhabditis briggsae. Nucleic Acids Res 32: 6388-6396.

GUY, J., GAN, J., SELFRIDGE, J., COBB, S. and BIRD, A. (2007). Reversal of neurological defects in a mouse model of Rett syndrome. Science 315: 11431147.

GUY, J., HENDRICH, B., HOLMES, M., MARTIN, J.E. and BIRD, A. (2001). A mouse Mecp2-null mutation causes neurological symptoms that mimic Rett syndrome. Nat Genet 27: 322-326.

HANSEN, R.S., WIJMENGA, C., LUO, P., STANEK, A.M., CANFIELD, T.K., WEEMAES, C.M. and GARTLER, S.M. (1999). The DNMT3B DNA methyltransferase gene is mutated in the ICF immunodeficiency syndrome. Proc Natl Acad Sci U S A 96: 14412-14417.

HARK, A.T., SCHOENHERR, C.J., KATZ, D.J., INGRAM, R.S., LEVORSE, J.M. and TILGHMAN, S.M. (2000). CTCF mediates methylation-sensitive enhancerblocking activity at the $\mathrm{H} 19 / \mathrm{lgf} 2$ locus. Nature 405: 486-489.

HASHIMOTO, H., HORTON, J.R., ZHANG, X., BOSTICK, M., JACOBSEN, S.E. and CHENG, X. (2008). The SRA domain of UHRF1 flips 5-methylcytosine out of the DNA helix. Nature 455: 826-9.

HENDRICH, B. and BIRD, A. (1998). Identification and characterization of a family of mammalian methyl-CpG binding proteins. Mol Cell Biol 18: 6538-6547.

HENDRICH, B., GUY, J., RAMSAHOYE, B., WILSON, V.A. and BIRD, A. (2001). Closely related proteins MBD2 and MBD3 play distinctive but interacting roles in mouse development. Genes Dev 15: 710-723.

HENDRICH, B., HARDELAND, U., NG, H.H., JIRICNY, J. and BIRD, A. (1999). The thymine glycosylase MBD4 can bind to the product of deamination at methylated CpG sites. Nature 401: 301-304.

HENDRICH, B. and TWEEDIE, S. (2003). The methyl-CpG binding domain and the evolving role of DNA methylation in animals. Trends Genet 19: 269-277.

HILDEBRAND, J.D. and SORIANO, P. (2002). Overlapping and unique roles for Cterminal binding protein 1 (CtBP1) and CtBP2 during mouse development. Mol Cell Biol 22: 5296-5307

HO, K.L., MCNAE, I.W., SCHMIEDEBERG, L., KLOSE, R.J., BIRD, A.P. and WALKINSHAW, M.D. (2008). MeCP2 binding to DNA depends upon hydration at methyl-CpG. Mol Cell 29: 525-31.

HOPFNER, R., MOUSLI, M., JELTSCH, J.M., VOULGARIS, A., LUTZ, Y., MARIN, C., BELLOCQ, J.P., OUDET, P. and BRONNER, C. (2000). ICBP90, a novel human CCAAT binding protein, involved in the regulation of topoisomerase Ilalpha expression. Cancer Res 60: 121-128.

HORIKE, S., CAI, S., MIYANO, M., CHENG, J.F. and KOHWI-SHIGEMATSU, T. (2005). Loss of silent-chromatin looping and impaired imprinting of DLX5 in Rett syndrome. Nat Genet 37: 31-40.

HUTCHINS, A.S., MULLEN, A.C., LEE, H.W., SYKES, K.J., HIGH, F.A., HENDRICH, B.D., BIRD, A.P. and REINER, S.L. (2002). Gene silencing quantitatively controls the function of a developmental trans-activator. Mol Cell 10: 81-91.

JELTSCH, A. (2006). On the enzymatic properties of Dnmt1: specificity, processivity, mechanism of linear diffusion and allosteric regulation of the enzyme. Epigenetics 1: 63-66.

JOHNSON, L.M., BOSTICK, M., ZHANG, X., KRAFT, E., HENDERSON, I., CALLIS, J. and JACOBSEN, S.E. (2007). The SRA methyl-cytosine-binding domain links DNA and histone methylation. Curr Biol 17: 379-384.

JONES, P.L., VEENSTRA, G.J., WADE, P.A., VERMAAK, D., KASS, S.U., LANDSBERGER, N., STROUBOULIS, J. and WOLFFE, A.P. (1998). Methylated DNA and MeCP2 recruit histone deacetylase to repress transcription. Nat Genet 19: 187-191.

JORGENSEN, H.F., BEN-PORATH, I. and BIRD, A.P. (2004). Mbd1 is recruited to both methylated and nonmethylated CpGs via distinct DNA binding domains. Mol Cell Biol 24: 3387-3395.

KAJI, K., CABALLERO, I.M., MACLEOD, R., NICHOLS, J., WILSON, V.A. and HENDRICH, B. (2006). The NuRD component Mbd3 is required for pluripotency of embryonic stem cells. Nat Cell Biol 8: 285-292.

KARAGIANNI, P., AMAZIT, L., QIN, J. and WONG, J. (2008). ICBP90, a novel methyl $\mathrm{K} 9 \mathrm{H} 3$ binding protein linking protein ubiquitination with heterochromatin formation. Mol Cell Biol 28: 705-717.

KELLY, K.F., SPRING, C.M., OTCHERE, A.A. and DANIEL, J.M. (2004). NLSdependent nuclear localization of p120ctn is necessary to relieve Kaisomediated transcriptional repression. J Cell Sci 117: 2675-2686.

KIEFER, H., CHATAIL-HERMITTE, F., RAVASSARD, P., BAYARD, E., BRUNET, I. and MALLET, J. (2005). ZENON, a novel POZ Kruppel-like DNA binding protein associated with differentiation and/or survival of late postmitotic neurons. Mol Cell Biol 25: 1713-1729.

KIM, S.W., FANG, X., JI, H., PAULSON, A.F., DANIEL, J.M., CIESIOLKA, M., VAN ROY, F. and MCCREA, P.D. (2002). Isolation and characterization of XKaiso, 
a transcriptional repressor that associates with the catenin Xp120(ctn) in Xenopus laevis. J Biol Chem 277: 8202-8208.

KIM, S.W., PARK, J.I., SPRING, C.M., SATER, A.K., JI, H., OTCHERE, A.A., DANIEL, J.M. and MCCREA, P.D. (2004). Non-canonical Wnt signals are modulated by the Kaiso transcriptional repressor and p120-catenin. Nat Cell Biol 6: 1212-1220.

KLOSE, R.J., SARRAF, S.A., SCHMIEDEBERG, L., MCDERMOTT, S.M., STANCHEVA, I. and BIRD, A.P. (2005). DNA binding selectivity of MeCP2 due to a requirement for $\mathrm{A} / \mathrm{T}$ sequences adjacent to methyl-CpG. Mol Cell 19: 667678.

KONDO, E., GU, Z., HORII, A. and FUKUSHIGE, S. (2005). The thymine DNA glycosylase MBD4 represses transcription and is associated with methylated p16(INK4a) and hMLH1 genes. Mol Cell Biol 25: 4388-4396.

KONDO, T. (2006). Epigenetic alchemy for cell fate conversion. Curr Opin Genet Dev 16: 502-50 7.

KRIAUCIONIS, S., PATERSON, A., CURTIS, J., GUY, J., MACLEOD, N. and BIRD, A. (2006). Gene expression analysis exposes mitochondrial abnormalities in a mouse model of Rett syndrome. Mol Cell Biol 26: 5033-5042.

KUNERT, N., MARHOLD, J., STANKE, J., STACH, D. and LYKO, F. (2003). A Dnmt2-like protein mediates DNA methylation in Drosophila. Development 130: 5083-5090.

LEONHARDT, H., PAGE, A.W., WEIER, H.U. and BESTOR, T.H. (1992). A targeting sequence directs DNA methyltransferase to sites of DNA replication in mammalian nuclei. Cell 71: 865-873.

LEWIS, J.D., MEEHAN, R.R., HENZEL, W.J., MAURER-FOGY, I., JEPPESEN, P., KLEIN, F. and BIRD, A. (1992). Purification, sequence, and cellular localization of a novel chromosomal protein that binds to methylated DNA. Cell69: 905-914.

LI, E. (2002). Chromatin modification and epigenetic reprogramming in mammalian development. Nat Rev Genet 3: 662-673.

LI, E., BESTOR, T.H. and JAENISCH, R. (1992). Targeted mutation of the DNA methyltransferase gene results in embryonic lethality. Cell 69: 915-926.

MARHOLD, J., KRAMER, K., KREMMER, E. and LYKO, F. (2004). The Drosophila MBD2/3 protein mediates interactions between the MI-2 chromatin complex and CpT/A-methylated DNA. Development 131: 6033-6039.

MARTIN CABALLERO, I., HANSEN, J., LEAFORD, D., POLLARD, S. and HENDRICH, B.D. (2009). The methyl-CpG binding proteins Mecp2, Mbd2 and Kaiso are dispensable for mouse embryogenesis, but play a redundant function in neural differentiation. PLOS ONE 4: e4315.

MARTINOWICH, K., HATTORI, D., WU, H., FOUSE, S., HE, F., HU, Y., FAN, G. and SUN, Y.E. (2003). DNA methylation-related chromatin remodeling in activitydependent BDNF gene regulation. Science 302: 890-893.

MEEHAN, R.R., LEWIS, J.D. and BIRD, A.P. (1992). Characterization of MeCP2, a vertebrate DNA binding protein with affinity for methylated DNA. Nucleic Acids Res 20: 5085-5092.

MEEHAN, R.R., LEWIS, J.D., MCKAY, S., KLEINER, E.L. and BIRD, A.P. (1989). Identification of a mammalian protein that binds specifically to DNA containing methylated CpGs. Cell 58: 499-507.

MILLAR, C.B., GUY, J., SANSOM, O.J., SELFRIDGE, J., MACDOUGALL, E., HENDRICH, B., KEIGHTLEY, P.D., BISHOP, S.M., CLARKE, A.R. and BIRD, A. (2002). Enhanced CpG mutability and tumorigenesis in MBD4-deficient mice. Science 297: 403-405

MUTO, M., KANARI, Y., KUBO, E., TAKABE, T., KURIHARA, T., FUJIMORI, A. and TATSUMI, K. (2002). Targeted disruption of Np95 gene renders murine embryonic stem cells hypersensitive to DNA damaging agents and DNA replication blocks. J Biol Chem 277: 34549-34555.

NAN, X., CAMPOY, F.J. and BIRD, A. (1997). MeCP2 is a transcriptional repressor with abundant binding sites in genomic chromatin. Cell 88: 471-481.

NAN, X., HOU, J., MACLEAN, A., NASIR, J., LAFUENTE, M.J., SHU, X., KRIAUCIONIS, S. and BIRD, A. (2007). Interaction between chromatin proteins MECP2 and ATRX is disrupted by mutations that cause inherited mental retardation. Proc Natl Acad Sci U S A 104: 2709-2714.

NAN, X., MEEHAN, R.R. and BIRD, A. (1993). Dissection of the methyl-CpG binding domain from the chromosomal protein MeCP2. Nucleic Acids Res 21: 4886-4892.

NAN, X., NG, H.H., JOHNSON, C.A., LAHERTY, C.D., TURNER, B.M., EISENMAN,
R.N. and BIRD, A. (1998). Transcriptional repression by the methyl-CpGbinding protein MeCP2 involves a histone deacetylase complex. Nature 393: 386-389.

NG, H.H., JEPPESEN, P. and BIRD, A. (2000). Active repression of methylated genes by the chromosomal protein MBD1. Mol Cell Biol 20: 1394-1406.

NG, H.H., ZHANG, Y., HENDRICH, B., JOHNSON, C.A., TURNER, B.M., ERDJUMENT-BROMAGE, H., TEMPST, P., REINBERG, D. and BIRD, A (1999). MBD2 is a transcriptional repressor belonging to the MeCP1 histone deacetylase complex. Nat Genet 23: 58-61.

NOMURA, T., KIMURA, M., HORII, T., MORITA, S., SOEJIMA, H., KUDO, S. and HATADA, I. (2008). MeCP2-dependent repression of an imprinted miR-184 released by depolarization. Hum Mol Genet. 17: 1192-1199.

OHKI, I., SHIMOTAKE, N., FUJITA, N., JEE, J., IKEGAMI, T., NAKAO, M. and SHIRAKAWA, M. (2001). Solution structure of the methyl-CpG binding domain of human MBD1 in complex with methylated DNA. Cell 105: 487-497.

OKANO, M., BELL, D.W., HABER, D.A. and LI, E. (1999). DNA methyltransferases Dnmt3a and Dnmt3b are essential for de novo methylation and mammalian development. Cell 99: 247-257.

OKANO, M., XIE, S. and LI, E. (1998a). Cloning and characterization of a family of novel mammalian DNA (cytosine-5) methyltransferases. Nat Genet 19: 219220.

OKANO, M., XIE, S. and LI, E. (1998b). Dnmt2 is not required for de novo and maintenance methylation of viral DNA in embryonic stem cells. Nucleic Acids Res 26: 2536-2540.

PAPAIT, R., PISTORE, C., NEGRI, D., PECORARO, D., CANTARINI, L. and BONAPACE, I.M. (2007). Np95 is implicated in pericentromeric heterochromatin replication and in major satellite silencing. Mol Biol Cell 18: 1098-1106.

PARK, J.I., KIM, S.W., LYONS, J.P., JI, H., NGUYEN, T.T., CHO, K., BARTON, M.C., DEROO, T., VLEMINCKX, K., MOON, R.T. et al. (2005). Kaiso/p120catenin and TCF/beta-catenin complexes coordinately regulate canonical Wnt gene targets. Dev Cell 8: 843-854.

PEREZ-TORRADO, R., YAMADA, D. and DEFOSSEZ, P.A. (2006). Born to bind: the BTB protein-protein interaction domain. Bioessays 28: 1194-1202.

PROKHORTCHOUK, A., HENDRICH, B., JORGENSEN, H., RUZOV, A., WILM, M., GEORGIEV, G., BIRD, A. and PROKHORTCHOUK, E. (2001). The p120 catenin partner Kaiso is a DNA methylation-dependent transcriptional repressor. Genes Dev 15: 1613-1618.

PROKHORTCHOUK, A., SANSOM, O., SELFRIDGE, J., CABALLERO, I.M., SALOZHIN, S., AITHOZHINA, D., CERCHIETTI, L., MENG, F.G., AUGENLICHT, L.H., MARIADASON, J.M. et al. (2006). Kaiso-deficient mice show resistance to intestinal cancer. Mol Cell Biol 26: 199-208.

RUZOV, A., DUNICAN, D.S., PROKHORTCHOUK, A., PENNINGS, S., STANCHEVA, I., PROKHORTCHOUK, E. and MEEHAN, R.R. (2004). Kaiso is a genome-wide repressor of transcription that is essential for amphibian development. Development 131: 6185-6194.

RUZOV, A., SAVITSKAYA, E., HACKETT, J.A., REDDINGTON, J.P., PROKHORTCHOUK, A., MADEJ, M.J., CHEKANOV, N., LI, M., DUNICAN, D.S., PROKHORTCHOUK, E. et al. (2009). The non-methylated DNA-binding function of Kaiso is not required in early Xenopus laevis development. Development 136: 729-38.

SAITO, M. and ISHIKAWA, F. (2002). The mCpG-binding domain of human MBD3 does not bind to $\mathrm{mCpG}$ but interacts with NuRD/Mi2 components HDAC1 and MTA2. J Biol Chem 277: 35434-35439.

SANSOM, O.J., BERGER, J., BISHOP, S.M., HENDRICH, B., BIRD, A. and CLARKE, A.R. (2003). Deficiency of Mbd2 suppresses intestinal tumorigenesis. Nat Genet 34: 145-147.

SARRAF, S.A. and STANCHEVA, I. (2004). Methyl-CpG binding protein MBD1 couples histone $\mathrm{H} 3$ methylation at lysine 9 by SETDB1 to DNA replication and chromatin assembly. Mol Cell 15: 595-605.

SASAI, N., MATSUDA, E., SARASHINA, E., ISHIDA, Y. and KAWAICHI, M. (2005). Identification of a novel BTB-zinc finger transcriptional repressor, CIBZ, that interacts with CtBP corepressor. Genes Cells 10: 871-885.

SEKIMATA, M. and HOMMA, Y. (2004). Sequence-specific transcriptional repression by an MBD2-interacting zinc finger protein MIZF. Nucleic Acids Res 32 : 590-597.

SHARIF, J., MUTO, M., TAKEBAYASHI, S., SUETAKE, I., IWAMATSU, A., ENDO, 
T.A., SHINGA, J., MIZUTANI-KOSEKI, Y., TOYODA, T., OKAMURA, K. et al. (2007). The SRA protein Np95 mediates epigenetic inheritance by recruiting Dnmt1 to methylated DNA. Nature 450: 908-912.

SHEN, L., KONDO, Y., GUO, Y., ZHANG, J., ZHANG, L., AHMED, S., SHU, J., CHEN, X., WATERLAND, R.A. and ISSA, J.P. (2007). Genome-wide profiling of DNA methylation reveals a class of normally methylated $\mathrm{CpG}$ island promoters. PLoS Genet 3: 2023-2036.

SHI, Y., SAWADA, J., SUI, G., AFFAREL, B., WHETSTINE, J.R., LAN, F., OGAWA, H., LUKE, M.P. and NAKATANI, Y. (2003). Coordinated histone modifications mediated by a CtBP co-repressor complex. Nature 422: 735-738.

SPRING, C.M., KELLY, K.F., O'KELLY, I., GRAHAM, M., CRAWFORD, H.C. and DANIEL, J.M. (2005). The catenin p120ctn inhibits Kaiso-mediated transcriptional repression of the beta-catenin/TCF target gene matrilysin. Exp Cell Res 305: 253-265.

STANCHEVA, I., COLLINS, A.L., VAN DEN VEYVER, I.B., ZOGHBI, H. and MEEHAN, R.R. (2003). A mutant form of MeCP2 protein associated with human Rett syndrome cannot be displaced from methylated DNA by notch in Xenopus embryos. Mol Cell 12: 425-435.

STANCHEVA, I., HENSEY, C. and MEEHAN, R.R. (2001). Loss of the maintenance methyltransferase, $x D n m t 1$, induces apoptosis in Xenopus embryos. EMBO J 20: 1963-1973.

STANCHEVA, I. and MEEHAN, R.R. (2000). Transient depletion of xDnmt1 leads to premature gene activation in Xenopus embryos. Genes Dev 14: 313-327.

SUZUKI, M.M. and BIRD, A. (2008). DNA methylation landscapes: provocative insights from epigenomics. Nat Rev Genet 9: 465-76.

TAKEBAYASHI, S., TAMURA, T., MATSUOKA, C. and OKANO, M. (2007). Major and essential role for the DNA methylation mark in mouse embryogenesis and stable association of DNMT1 with newly replicated regions. Mol Cell Biol 27: 8243-8258.

TAKIZAWA, T., NAKASHIMA, K., NAMIHIRA, M., OCHIAI, W., UEMURA, A., YANAGISAWA, M., FUJITA, N., NAKAO, M. and TAGA, T. (2001). DNA methylation is a critical cell-intrinsic determinant of astrocyte differentiation in the fetal brain. Dev Cell 1: 749-758.

TUDOR, M., AKBARIAN, S., CHEN, R.Z. and JAENISCH, R. (2002). Transcriptional profiling of a mouse model for Rett syndrome reveals subtle transcriptional changes in the brain. Proc Natl Acad Sci U S A 99: 15536-15541.

UNOKI, M., NISHIDATE, T. and NAKAMURA, Y. (2004). ICBP90, an E2F-1 target, recruits $\mathrm{HDAC} 1$ and binds to methyl-CpG through its SRA domain. Oncogene 23: 7601-7610.

VAN ROY, F.M. and MCCREA, P.D. (2005). A role for Kaiso-p120ctn complexes in cancer? Nat Rev Cancer 5: 956-964.

WALSH, C.P. and XU, G.L. (2006). Cytosine methylation and DNA repair. Curr Top Microbiol Immunol 301: 283-315.

WANG, Y., JORDA, M., JONES, P.L., MALESZKA, R., LING, X., ROBERTSON, H.M., MIZZEN, C.A., PEINADO, M.A. and ROBINSON, G.E. (2006). Functional CpG methylation system in a social insect. Science 314: 645-647.
WATANABE, S., ICHIMURA, T., FUJITA, N., TSURUZOE, S., OHKI, I., SHIRAKAWA, M., KAWASUJI, M. and NAKAO, M. (2003). Methylated DNA-binding domain 1 and methylpurine-DNA glycosylase link transcriptional repression and DNA repair in chromatin. Proc Natl Acad Sci U S A 100: 12859-12864.

WEBER, M., HELLMANN, I., STADLER, M.B., RAMOS, L., PAABO, S., REBHAN, M. and SCHUBELER, D. (2007). Distribution, silencing potential and evolutionary impact of promoter DNA methylation in the human genome. Nat Genet 39: 457-466.

WEBER, A., MARQUARDT, J., ELZI, D., FORSTER, N., STARKE, S., GLAUM, A., YAMADA, D., DEFOSSEZ, P.A., DELROW, J., EISENMAN, R.N. et al. (2008). Zbtb4 represses transcription of P21CIP1 and controls the cellular response to p53 activation. EMBO J 27: 1563-74.

WOO, H.R., PONTES, O., PIKAARD, C.S. and RICHARDS, E.J. (2007). VIM1, a methylcytosine-binding protein required for centromeric heterochromatinization. Genes Dev 21: 267-277.

XU, G.L., BESTOR, T.H., BOURC'HIS, D., HSIEH, C.L., TOMMERUP, N., BUGGE, M., HULTEN, M., QU, X., RUSSO, J.J. and VIEGAS-PEQUIGNOT, E. (1999). Chromosome instability and immunodeficiency syndrome caused by mutations in a DNA methyltransferase gene. Nature 402: 187-191.

YASUI, D.H., PEDDADA, S., BIEDA, M.C., VALLERO, R.O., HOGART, A., NAGARAJAN, R.P., THATCHER, K.N., FARNHAM, P.J. and LASALLE, J.M. (2007). Integrated epigenomic analyses of neuronal MeCP2 reveal a role for long-range interaction with active genes. Proc Natl Acad Sci U S A 104: 1941619421.

YOON, H.G., CHAN, D.W., REYNOLDS, A.B., QIN, J. and WONG, J. (2003). NCoR mediates DNA methylation-dependent repression through a methyl $\mathrm{CpG}$ binding protein Kaiso. Mol Cell 12: 723-734.

YOUNG, J.I., HONG, E.P., CASTLE, J.C., CRESPO-BARRETO, J., BOWMAN, A.B., ROSE, M.F., KANG, D., RICHMAN, R., JOHNSON, J.M., BERGET, S. et al. (2005). Regulation of RNA splicing by the methylation-dependent transcriptional repressor methyl-CpG binding protein 2. Proc Natl Acad Sci U S A 102: 17551-17558.

ZEMACH, A. and GRAFI, G. (2007). Methyl-CpG-binding domain proteins in plants: interpreters of DNA methylation. Trends Plant Sci 12: 80-85.

ZHANG, Q., YOSHIMATSU, Y., HILDEBRAND, J., FRISCH, S.M. and GOODMAN, R.H. (2003). Homeodomain interacting protein kinase 2 promotes apoptosis by downregulating the transcriptional corepressor CtBP. Cell 115: 177-186.

ZHANG, Y., NG, H.H., ERDJUMENT-BROMAGE, H., TEMPST, P., BIRD, A. and REINBERG, D. (1999). Analysis of the NuRD subunits reveals a histone deacetylase core complex and a connection with DNA methylation. Genes Dev 13: 1924-1935.

ZHAO, X., UEBA, T., CHRISTIE, B.R., BARKHO, B., MCCONNELL, M.J., NAKASHIMA, K., LEIN, E.S., EADIE, B.D., WILLHOITE, A.R., MUOTRI, A.R. et al. (2003). Mice lacking methyl-CpG binding protein 1 have deficits in adult neurogenesis and hippocampal function. Proc Natl Acad Sci U S A 100: 67776782 . 


\section{Further Related Reading, published previously in the Int. J. Dev. Biol.}

See our Special Issue Mammalian Reproduction and Development edited by Brigid Hogan at: http://www.ijdb.ehu.es/web/contents.php?vol=45\&issue=3

Unaltered imprinting establishment of key imprinted genes in mouse oocytes after in vitro follicle culture under variable folliclestimulating hormone exposure

Ellen Anckaert, Tom Adriaenssens, Sergio Romero, Sarah Dremier and Johan Smitz

Int. J. Dev. Biol. (2009) 52 in Press

Imprinting of mammalian male gametes is gene specific and does not occur at a single stage of differentiation María D. Boyano, Noelia Andollo, María M. Zalduendo and Juan Aréchaga

Int. J. Dev. Biol. (2008) 52: 1105-1111

Hypomethylation of paternal DNA in the late mouse zygote is not essential for development

Zbigniew Polanski, Nami Motosugi, Chizuko Tsurumi, Takashi Hiiragi and Steffen Hoffmann

Int. J. Dev. Biol. (2008) 52: 295-298

DNA methylation state is preserved in the sperm-derived pronucleus of the pig zygote

Young-Sun Jeong, Seungeun Yeo, Jung-Sun Park, Deog-Bon Koo,

Won-Kyung Chang, Kyung-Kwang Lee and Yong-Kook Kang

Int. J. Dev. Biol. (2007) 51: 707-714

Histone methylation defines epigenetic asymmetry in the mouse zygote Katharine L Arney, Siqin Bao, Andrew J Bannister, Tony Kouzarides and M Azim Surani

Int. J. Dev. Biol. (2002) 46: 317-320

DNA methylation of the U2af1-rs1 gene in embryonic stem cells and embryonal carcinoma cells after RA-induced differentiation and apoptosis N Andollo, MD Boyano, A Asumendi, MM Zalduendo, J Arechaga Int. J. Dev. Biol. (2001) 45: S149-S150

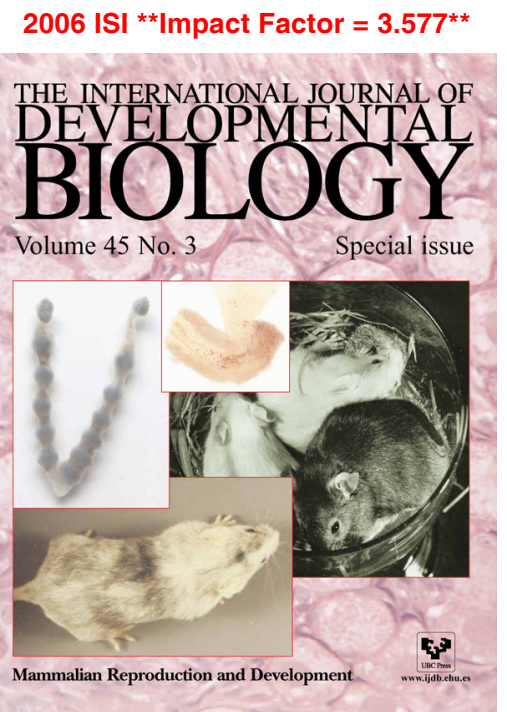

